\title{
ATLAS REUSE: studying the metabolic evolution of Barcelona
}

\author{
R. Sauquet Llonch \& D. Taskin \\ "HABITAR" at ETSAB, UPC Polytechnic University of Catalonia, Spain
}

\begin{abstract}
Transformations in cities are becoming increasingly more related to reuse practices than substitution processes. In Barcelona, new programs and activities have always used existent architecture to integrate in the city. In 2014, the research group HABITAR (UPC Universitat Politècnica de Catalunya - Barcelona Tech) won a grant from the Spanish Economy Ministry to develop an extensive research about "reuse" in Barcelona. The objective is to answer the question of how reuse is conditioned by the city and, vice versa, how the city is conditioned by reuse. It is also within the objectives to study the building capacity of adaptation, depending on its typology, dimension, configuration and location in the city. The paper will explain some details of this work that is currently in progress. The group is studying buildings built from the first century to the present. Around 420 cases are selected and analysed with the aim of not only obtaining statistic information, but also understanding the influence of these changes on the architecture and the city. The information, by being treated with data and geo-localization programmes, facilitates the final and the main objective of the project: the production of an atlas of reuse of Barcelona, a theory of reutilization, and a protocol of reprogramming for professionals.
\end{abstract}

Keywords: Barcelona, atlas, reuse, urban metabolism, depreciation, use, architecture, urban planning.

\section{Project description}

\subsection{Introduction and state of the art}

Utilisation of the existing building stock is one of the most primary manifestations of sustainability applied to architecture. This idea constitutes the origin and the 
focus of the investigation group HABITAR (Universitat Politècnica de Catalunya - BarcelonaTECH), which has pursued its investigations in the field of sustainability since its formation, with an emphasis on the authentic meaning of the terminology.

The concept of utilization, in relation to abandonment and obsolescence, was first elaborated by HABITAR in the context of "ReHabitar", an exhibition realised in Galería Nuevos Ministerios de Madrid between 2010 and 2012, and in its corresponding publication ReHabitar en nueve episodios [1]. The theme was specifically elaborated in the chapter titled Abandono y oportunidad, in which the obsolescence of buildings was linked to city's capacity of revitalisation through the interior. The concept of "revitalisation of the city", led to the publication of a second book, Rehabitar la casa, la calle y la ciudad [2], in which series of alternatives were presented via six different case studies in Barcelona. The book revealed a significant number of representative buildings located in Barcelona, which lack an adequate use, but possess a potential to develop new activities with grand urban repercussion. It was consolidated with a small collection of buildings with successful changes of use such as the case of Reales Atarazanas. The collection, later on became the basis of the project ATLAS REUSE, the subject of this paper. The book also manifested, that the depreciation of buildings has always been a common practice in the regeneration of the city, a practice that almost forms a part of its metabolism. In this context, the project ATLAS REUSE, investigates the historical evolution of buildings which had changes of use, and studies their relation with Barcelona, as well as the very nature of these transformations which took place.

Even though there are already numerous publications which focus on the reuse of buildings, they mostly possess a specific character which differs from the investigation that we currently carry. Some of them tackle the role of programming in the transformation of buildings, such as the adaptation of commercial buildings in old structures [3], while others investigate the effects of changes of use in buildings of architectural heritage [4], or focus on precise locations such as the port of Barcelona [5]. There is clearly a lack of studies, which directly focus on the impact of reuse, both in relation to the urban context, and to the very nature of the transformations which occur within the architecture of these buildings.

Therefore, our interest lies within the study of this phenomenon at an urban scale; a phenomenon which augmented as the city continued its extension. In Barcelona, to reprogram the structures which fell into disuse is almost a daily routine, which has increased not only in number, but also in diversity and complexity. These buildings have not been studied, nor inventoried, prior to the project of ATLAS REUSE, with the emphasis on the fact that they belong to a particular group in the city: buildings which have changed use. This group contains well-known buildings of universal exhibitions and international events. The exhibitions of 1888 and 1929, the Olympic Games of 1992, and the Cultural Forum of 2004 were events which served the city for reasons beyond their content, success and diffusion. Their common characteristic was that, they all generated new constructions, which had the capacity to cover other necessities, once these 
events that they were constructed for came to an end. This became a theme which is ever more present in the design of these international organizations worldwide.

These examples lead to a relevant observation: The reuse and the depreciation of these buildings are within their DNA, and therefore, their expiration becomes something programmed and is considered almost unquestionable. Could this characteristic be comparable to the rest of the building stock in the city? It is just a question of considering that, perhaps, the buildings which fall into disuse, are not unexpected accidents, but, something which the city constantly produces, and which, therefore, must be programmed. A significant case in this context is the "Adaptive Reuse Ordinance" passed in Los Angeles in 1999, and revised in 2003, which provided some particular conditions for the transformation of obsolete office buildings into residential complexes. This particular legislation demonstrated that, with the adequate regulation, the reuse can convert itself into a motor of urban and economical revitalisation.

In Barcelona, as in Los Angeles, there are currently a considerable number of unoccupied buildings, which create a phenomenon that must be a part of city planning. Torre Agbar, one of the examples with less than 10 years of existence, is recently acquired by a North American hotel management group to be converted into a hotel, at an operation cost of 150 million, and an estimated inversion of 35 million, all to be spent in its modification. Do we know the consequences of such transformation and its possible impacts on the city? The project ATLAS REUSE, in this sense, aims to generate knowledge about the phenomenon of reuse, and contribute to the improvements of reprogramming instruments. Given the fact that the quality of cities depends on the life of its buildings, among other things, their abandonment and reprogramming have important effects, which condition, not only their close context, but also the functioning of the city at a greater scale. This study aims to contribute to the recognition of this.

\subsection{Goals}

The project has three objectives in general:

- Elaborating an "atlas of depreciated buildings" in Barcelona.

- Formulating a "theory of reutilisation in architecture".

- Creating a "protocol of reprogramming", which would serve the practical application of the theory.

The initial hypothesis departs from the "Atlas of depreciated buildings", which inventories the buildings in Barcelona, from all time periods and with diverse formal, constructive, typological, urban and historical characteristics, with the emphasis on the change of use. The hypothesis is that, this particular inventory would serve to recognise some guidelines, which can facilitate the resolution of similar examples. The detailed analysis of some particular cases, together with a systematic study of their characteristics and transformation process, would permit the deduction of these guidelines, which are relative to adaptive responses created by diverse changes of use. They would also generate relative information about the capacity of certain buildings to receive various programs which they were not conceived to have in the first place. 
The "Theory of Reutilization" which would emerge from the elaboration of an atlas, will manifest that the "life of a building" is directly linked to the relation between its original and new use at an architectural level. One of its outcomes would be clarifying the functionalist idea, through the buildings with a form which dictates their use. In our point of view, by studying the form/function combination in a realistic manner, and in each case study, it would be clear that the flexibility in architecture depends on both things: that the building allows it and that the use fits in the building, which can be improved on some occasions, when there is a certain need for adaptation. The theory, in this context, allows the reinterpretation of the idea of "type" in architecture, which adds complexity to the terminology, despite its exclusive focus on the change of use and its urban implications.

In parallel, the study aims to prove that the buildings which fall into disuse are not accidents, but rather something that the city produces regularly and which should be subject to reprogramming. The subject field of atlas becomes significant in this sense, for the fact that the city acts as a system consisting of elements in interaction, that would permit understanding the nature of the singular transformations better. The hypothesis is that, via the general and specific guidelines, a "protocol of reprogramming" can be established. This protocol would consist of a series of strategies that would improve the process of reuse, and facilitate the planning of municipal politics to serve the whole city in the long run. Such a protocol would prove quite useful, not only for Barcelona, but also for other cities, which encounter the same problems currently, or would do in the future. Finally, the Protocol would also make it clear, that grouping these buildings in a different operative classification, becomes ever more necessary in order to create a proper building REGULATION which blends with the existing ones (technical building code, fire prevention regulation and etc.) and establishes particular conditions for the buildings to preserve their singular characteristics, without which, they would be incompatible with the new use.

\section{Research process}

The project is currently at the halfway point. So far, 422 buildings have been selected to gather information for the investigation, following the criteria which is to be explained in the following section. For each case study, a data sheet has been elaborated with relevant information about the original and new uses, as well as descriptive graphic material. The details of the process are as follows.

\subsection{Case study selection criteria and methodology}

The primary phase of the project consisted of establishing a selection criteria for the case studies. One of the important decisions taken in this context, is to exclude the instances in which the change of use has been partial, and not has affected the totality of the building. However, some exceptions are considered for this criteria, such as theaters, cinemas and nightclubs, considering the fact that the ground floor constitutes an architectural element with certain autonomy in such cases. Another decision is to exclude the buildings which underwent a physical 
transformation at a substantial level at the moment of its change of use, such as the buildings which were demolished in the interior but preserved their façades, and the buildings which were subject to such an advance transformation that became unrecognisable.

For the selection of cases, we first resorted to architectural guides of Barcelona, since they provide easily accessible inventories of buildings of interest. After this first phase of browsing, we prepared a preliminary list of approximately 300 buildings. Next, we consulted the architectural heritage catalogue of Barcelona, considering the fact that the majority of the buildings have changed use for their "under protection" status. Finally, we included the publicly well-known buildings which appear in the press or which have been documented in newspaper archives. All together, we created a list of 422 buildings to be analysed. It is important to note that this list obviously does not include all the buildings which changed use in Barcelona, but, provides a sufficient and significant sample to reach some conclusions.

\subsection{Researched data}

For each case study, we have researched relevant information regarding the nature of the change of use via graphic documentation such as plans, sections, elevations and photographs, which reflect each "moment" of the building, corresponding to its original condition as well as the following transformations.

The bibliography that was consulted in the first phase of the investigation, consisted of the architectural guides written by Hernández-Cros et al. [6], others that are specialised in time periods or architectural movements, including the edition by ACTAR [7], the compilation by Muga and García [8] and La Arquitectura de los años cincuenta by Monteys [9]. Some monographs dedicated to certain typologies were also consulted in this process, such as La Arquitectura de la Industria: 1925-1965 by the DOCOMOMO foundation [10].

Next, we consulted to some specialised web pages to complement the missing data, such as the official web page of the municipality of Barcelona and data sheets of the architectural heritage catalogue. This process was followed by the consultation to municipal archives of Barcelona to obtain some further data that was deposited with licenses, to district archives and to COAC, Architects' Association of Catalonia.

The data that was obtained for each building has various focuses that are all related to the use and the activity, including the information in regards to the initial period of construction as well each change of use, considering these as temporary "moments" which define the life of the building once all put together.

For the original use, the following data has been researched:

- Name of the building at the time of its construction.

- The year of construction.

- The address.

- The architect of the project.

- The definition of the original use.

- The ownership of the building at the time of its construction. 
- The occupancy of the original use (whether it included the totality of the building or only parts of it).

For each change of use, the following data has been researched:

- Name of the building after the change of use.

- The year of the change of use.

- The architect in charge of the project.

- The definition of the new use.

- The year of the finalisation (in case it is not the actual use).

This group of data was researched for each change of use and was repeated as many times as the case study had a new function. To present day, the maximum number of changes of use that a single building had, according to our data, is four. Although we can estimate that this number is probably higher for historical buildings, it has not been quite possible to gather information regarding all time periods.

In order to organise the information in a systematic way to be able to compare the totality of the cases, we focused on the category of "use", and divided it into three different sections under the titles of "generic use 1", "generic use 2" and "generic use 3". The table which we used as a reference in this categorisation is illustrated in table 1 .

The template of a data sheet was designed to summarise all the gathered information and clearly demonstrate each change of use that the building had. At the top of each data sheet, a photograph is used in order to identify each case, followed by other graphic materials such as plans and sections which demonstrate the effects of the changed use on the architecture of the building. A sample data sheet is illustrated in fig. 1 .

\section{First results}

Once the data was organised, we made our first attempt to obtain some conclusions about general properties in statistics which had outstanding results. It should be made clear that these results were achieved through a certain level of generalisation, focusing only on the generic use 1, as illustrated in the table in fig. 1. However, these statistics still provide an outlook on the reality of the cases that were included in our study which, as explained earlier, do not consist of all the buildings that changed use, but a selection of them. In this context, the statistics provide an approximated idea of what is taking place in the city in terms of change of use, although the possibility of a slight deviation should be taken into consideration. It should also be noted down that, the results are going to be explained without too much detail of how and why, which would be the topic of a more profound study and documentation. 
Table 1: Building use categories.

\begin{tabular}{|c|c|c|}
\hline \multirow[t]{2}{*}{ 1. Housing } & 1.1. Single-family & $\begin{array}{l}\text { Villa, Urban house, } \\
\text { Palace, Masía }\end{array}$ \\
\hline & 1.2. Multi-family & Apartment building \\
\hline \multirow{2}{*}{ 2. Residential } & 2.1. Hotel & $\begin{array}{l}\text { Hotel, Hostel/Guesthouse, } \\
\text { Touristic apartment }\end{array}$ \\
\hline & 2.2. Residence & $\begin{array}{l}\text { Student residences, } \\
\text { Nursing homes }\end{array}$ \\
\hline \multirow[t]{2}{*}{ 3. Commercial } & 3.1. Commercial & $\begin{array}{l}\text { Commercial center, } \\
\text { Department stores, Small } \\
\text { business }\end{array}$ \\
\hline & 3.2. Restaurant & Restaurant \\
\hline \multirow{2}{*}{ 4. Offices } & 4.1. Offices & $\begin{array}{l}\text { Offices, Banks, } \\
\text { Multinationals, Cultural } \\
\text { production }\end{array}$ \\
\hline & 4.2. Institutional offices & $\begin{array}{l}\text { Service companies, } \\
\text { Consulates, Professional } \\
\text { Associations }\end{array}$ \\
\hline 5. Industrial & 5.1. Industrial & $\begin{array}{l}\text { Factory, Parking, } \\
\text { Technical elements, } \\
\text { Industrial warehouses, } \\
\text { Laboratories }\end{array}$ \\
\hline \multirow[t]{2}{*}{ 6. Sanitary } & 6.1. Hospital service & $\begin{array}{l}\text { Hospital, Sanatorium, } \\
\text { Clinics }\end{array}$ \\
\hline & 6.2. Healthcare service & Healthcare centers \\
\hline \multirow[b]{2}{*}{ 7. Religious } & 7.1. Religious temples & Church, Cathedral \\
\hline & 7.2. Religious residencies & $\begin{array}{l}\text { Monastry/Convent, } \\
\text { Orphanage/Refuge }\end{array}$ \\
\hline \multirow[t]{2}{*}{ 8. Cultural } & 8.1. Cultural & $\begin{array}{l}\text { Library, Museum, Art } \\
\text { center, Cultural } \\
\text { association, Exhibition }\end{array}$ \\
\hline & 8.2. Spectacles & $\begin{array}{l}\text { Theater/Movie theater, } \\
\text { Auditorium }\end{array}$ \\
\hline 9. Recreational & 9.1. Recreational & $\begin{array}{l}\text { Party halls/Clubs, Civic } \\
\text { centers, Others }\end{array}$ \\
\hline \multirow{3}{*}{ 10. Educational } & 10.1. Primary/Secundary ed. & $\begin{array}{l}\text { Nursery school, Daycare } \\
\text { centers, School/High } \\
\text { school }\end{array}$ \\
\hline & 10.2. Higher education & University \\
\hline & 10.3. Training center & Training center \\
\hline 11. Sports & 11.1. Sports & $\begin{array}{l}\text { Sports center, } \\
\text { Gymnasiums }\end{array}$ \\
\hline \multirow{3}{*}{ 12. Institutional } & 12.1. Military & Barracks, Defense towers \\
\hline & 12.2. Civil & $\begin{array}{l}\text { Prison, Post office, Police } \\
\text { station, Fire station, } \\
\text { Administration, Market, } \\
\text { Archive/Warehouse }\end{array}$ \\
\hline & 12.3. Transportation & $\begin{array}{l}\text { Metro/Train station, } \\
\text { Depots }\end{array}$ \\
\hline
\end{tabular}




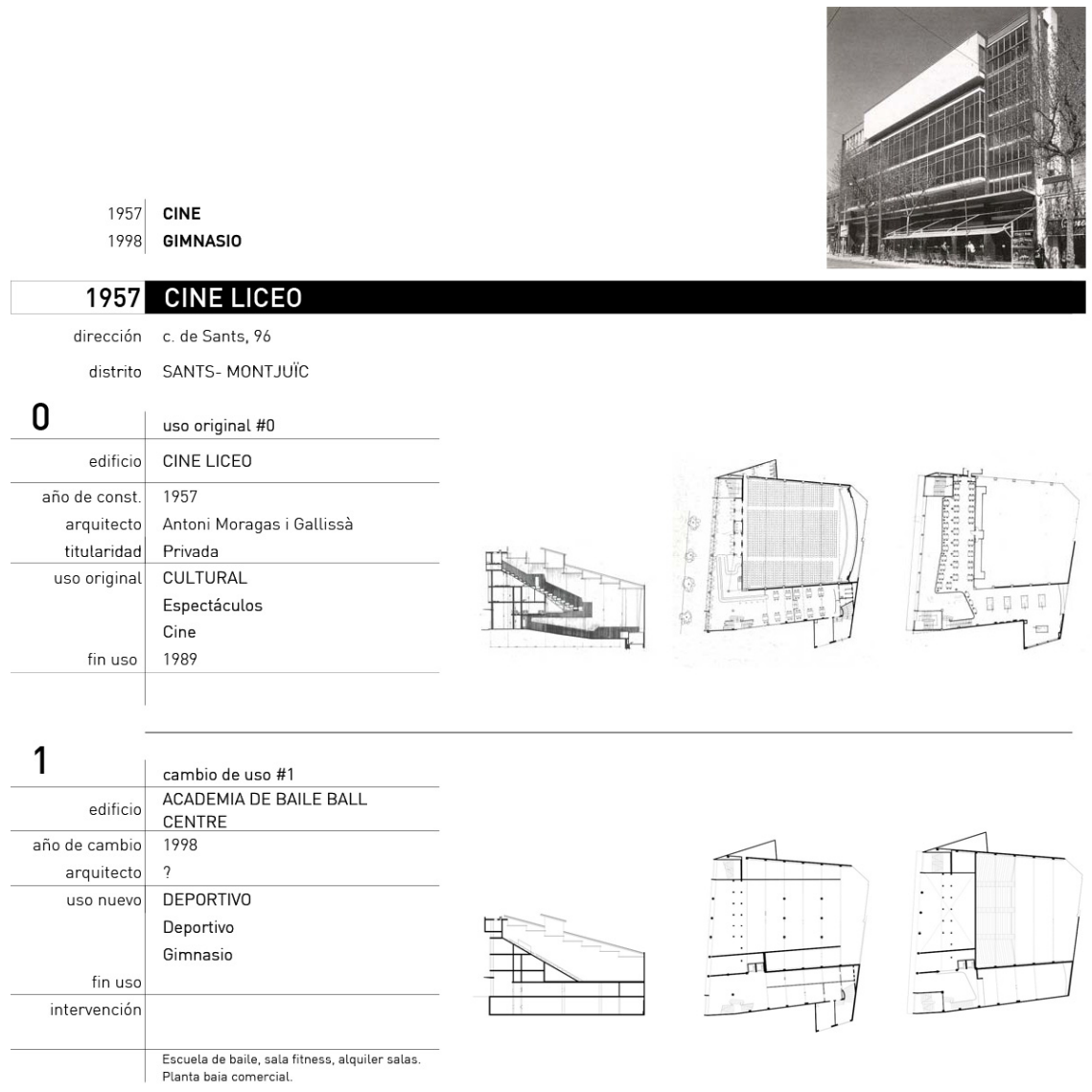

Figure 1: Sample of data sheet.

\subsection{The reality of cases}

According to our first results, the use that has provided more space for the reutilisation in Barcelona, is "housing", being the most frequent original use that we detected, with a percentage of $52.48 \%$, constituting more than half of our case studies (fig. 2). "Industrial" follows "housing", with a percentage of $21.80 \%$. "Religious" buildings constitute $8.06 \%$ of the case studies, which can perhaps be linked to the historical transformation of Spain, from a religious state to a secular one, even though this observation needs further study to be consolidated.

At another extreme, there are the buildings which had less changes of use, as in the cases of "recreational", "commercial", "residential" (hotels and guesthouses), "educational" and "sports". At this point, we found only one example with the original use of sports which went through a change of use. These results could be explained with the fact that these buildings can be regarded as "facilities", and Spain, as a country, has witnessed an increase in the number of 
facilities, which mostly replaced the obsolete industrial buildings, religious complexes and houses. The buildings which were facilities at the beginning, continue to be so.

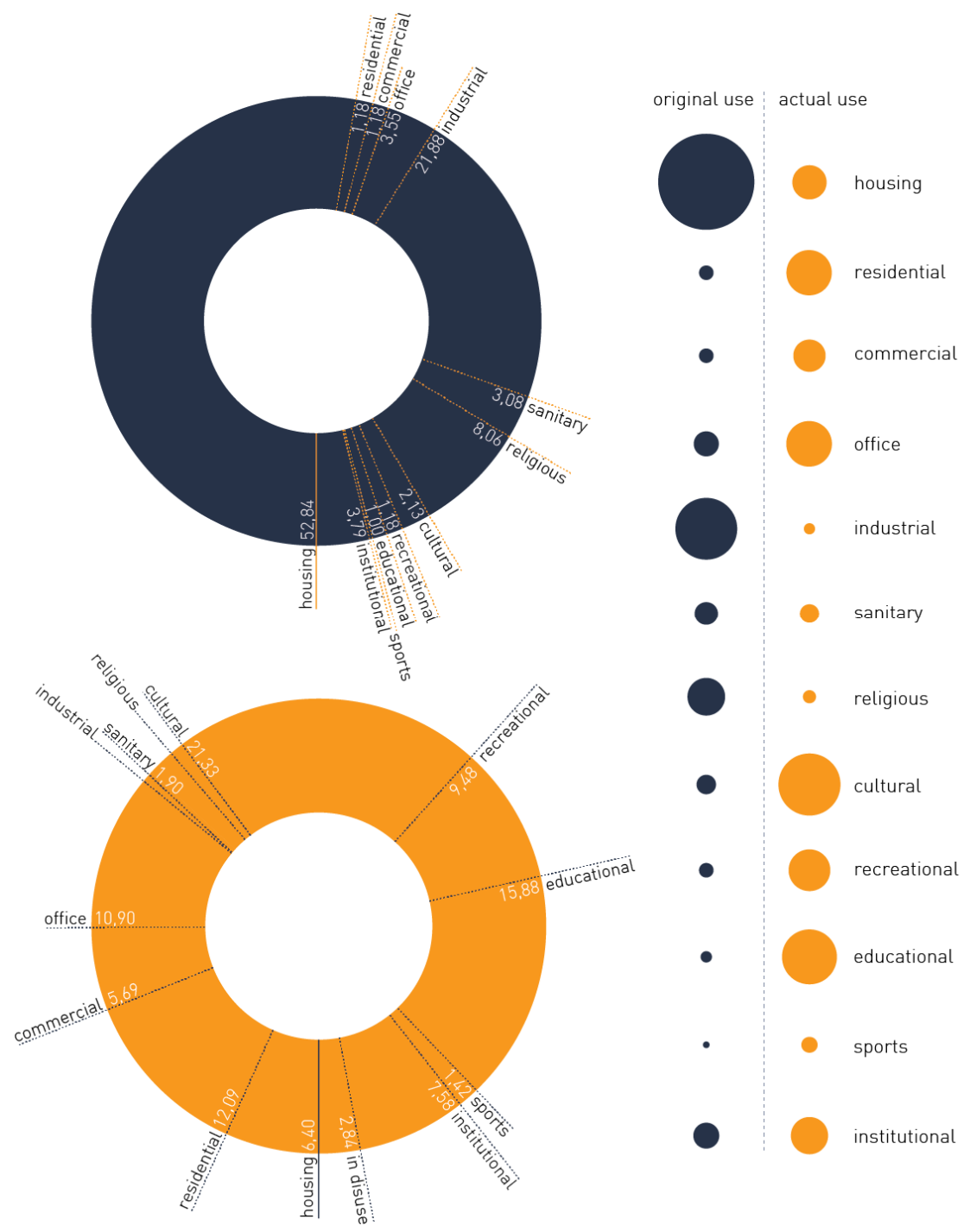

Figure 2: Comparison of orginal use and actual use in percentage.

If we take another approach and analyse our case studies according to their actual uses, we see that the most common one is "cultural", with a percentage of $21.33 \%$, which renders it as the most "reuser" function. "Educational" follows 
"cultural" with a percentage of $15.88 \%$, followed by "residential" with $12.09 \%$, and "office" with $10.90 \%$. When compared with the previous analysis, it is clear that these statistics are less polarized and more homogenous. The categories which stand out as less "reuser" are "industrial", with a percentage of $0.7 \%$, "religious" with $0.95 \%$, and sports with $1.42 \%$. The scarcity of the last two functions could be explained by the fact that there are less of them in the city, and that they perhaps require a more specialised building typology.

When we focus on the districts where the case studies are located, Ciutat Vella stands out with a percentage of $31.52 \%$. Sarrià - Sant Gervasi follows with $16.35 \%$, Eixample with $13.27 \%$, and Sant Martí with $11.14 \%$. The remaining districts in order form the one with more changes of use to the less, is as follows: Sants Montjuïc, Les Corts, Horta-Guinardó, Gràcia, Sant Andreu and finally Nou Barris (fig. 3).

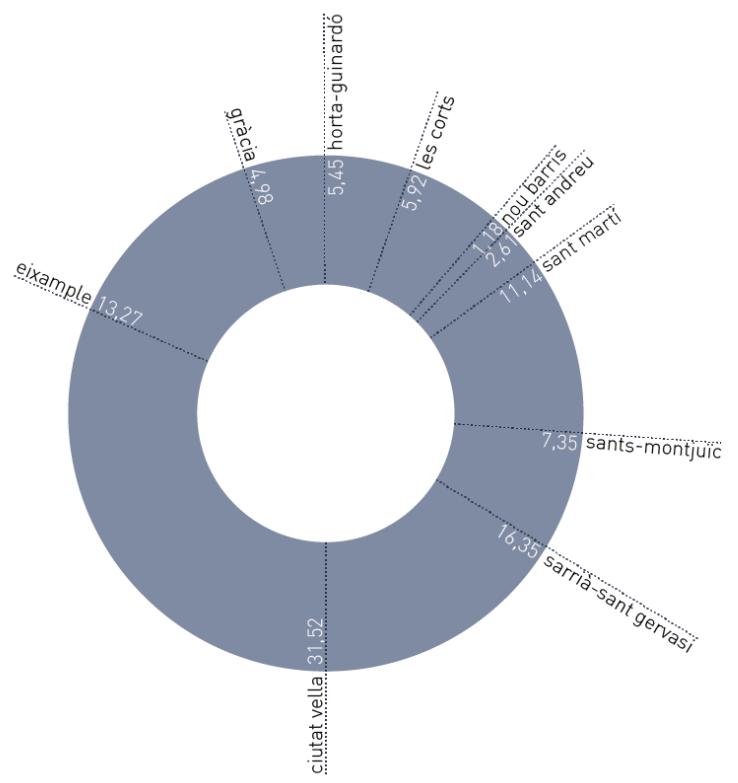

Figure 3: Percentages according to districts.

\subsection{In progress}

At the moment, the investigation is still in progress. The results that are presented here are the first outlooks on the data. However, at this point, we have detected some gaps in our database, such as the low percentage of hotels, which contradicts with the reality that Barcelona is one of the European cities in which the quantity of such establishments have increased recently in remarkable levels. Our intention is to extend our database through investigations in specific subject fields in order 
to increase the number of case studies and adjust our conclusions with greater precision.

As it is explained earlier, the documents that we plan to generate are "atlas of depreciated buildings", "Theory of reutilization in architecture" and "Protocol of reprogramming", which will require not only a thorough analysis of statistics, but also observations and research on metamorphosis of each building, together with its context in the city. We hope that the selection of case studies will permit us to achieve these objectives and the results will make a breakthrough in the study of the metabolism of cities.

\section{References}

[1] Habitar UPC, ReHabitar en nueve episodios, Madrid, 2012. ISBN:978-84616-0054-0.

[2] Habitar-grupo de investigación, AAVV. Rehabitar. La casa, el carrer i la ciutat. Barcelona com a cas d'estudi. Financiado por el Programa recer Caixa, convocatoria 2010. Editado en Barcelona: Plan B, 2013.

[3] Gray, Carol J. Adaptive reuse : shopping malls from old buildings. Monticello, Ill. : Council of Planning Librarians, 1977.

[4] Austin, Richard L. et alt. Adaptive reuse : issues and case studies in building preservation. New York, Van Nostrand Reinhold, 1988.

[5] Tatjer, Mercedes. "La construcción del espacio costero, siglos XIX-XX: del mundo portuario al mundo del ocio: el caso del puerto de Barcelona, 18561936”. Puertos y sistemas portuarios (siglos XVI-XX) : actas del Coloquio Internacional el Sistema Portuario Español, Madrid, CEHOPU/CSIC, 1996.

[6] Hernández-Cros, J., Mora, G., Pouplana, X. Arquitectura de Barcelona. Demarcació de Barcelona del Collegi d'Arquitectes de Catalunya, Barcelona, 1990.

[7] Gausa, M., Cervelló, M., Pla, M., Devesa, R. Barcelona: guía de arquitectura moderna. Actar - Ajuntament de Barcelona, Barcelona, 2013.

[8] Muga, P., García, L. Barcelona: arquitectura moderna: 1929-1979. Polígrafa: Ajuntament de Barcelona, Barcelona, 2006.

[9] Monteys, X. L'Arquitectura dels anys 50 a Barcelona: octubre de 1999. Enginyeria i Arquitectura La Salle, Universitat Ramon Lull, Barcelona, 1999.

[10] García, C., Landrove, S., Tostoes, A. La Arquitectura de la Industria: 1925 1965. Fundación DOCOMOMO Ibérico, DL, Barcelona, 2005. 